IZA DP No. 5591

Retaining through Training: Even for Older Workers

Matteo Picchio

Jan C. van Ours

March 2011 


\title{
Retaining through Training: Even for Older Workers
}

\author{
Matteo Picchio \\ Tilburg University, CentER, ReflecT \\ and IZA \\ Jan C. van Ours \\ Tilburg University, CentER, ReflecT, \\ University of Melbourne, CESifo, CEPR and IZA
}

\section{Discussion Paper No. 5591 \\ March 2011}

\author{
IZA
}

P.O. Box 7240

53072 Bonn

Germany

Phone: +49-228-3894-0

Fax: +49-228-3894-180

E-mail: iza@iza.org

\begin{abstract}
Any opinions expressed here are those of the author(s) and not those of IZA. Research published in this series may include views on policy, but the institute itself takes no institutional policy positions.

The Institute for the Study of Labor (IZA) in Bonn is a local and virtual international research center and a place of communication between science, politics and business. IZA is an independent nonprofit organization supported by Deutsche Post Foundation. The center is associated with the University of Bonn and offers a stimulating research environment through its international network, workshops and conferences, data service, project support, research visits and doctoral program. IZA engages in (i) original and internationally competitive research in all fields of labor economics, (ii) development of policy concepts, and (iii) dissemination of research results and concepts to the interested public.
\end{abstract}

IZA Discussion Papers often represent preliminary work and are circulated to encourage discussion. Citation of such a paper should account for its provisional character. A revised version may be available directly from the author. 
IZA Discussion Paper No. 5591

March 2011

ABSTRACT

\section{Retaining through Training: Even for Older Workers}

This paper investigates whether on-the-job training has an effect on the employability of workers. Using data from the Netherlands we disentangle the true effect of training incidence from the spurious one determined by unobserved individual heterogeneity. We also take into account that there might be feedback from shocks in the employment status to future propensity of receiving firm-provided training. We find that firm-provided training significantly increases future employment prospects. This finding is robust to a number of robustness checks. It also holds for older workers, suggesting that firm-provided training may be an important instrument to retain older workers at work.

JEL Classification: C33, C35, J21, J24, M53

Keywords: $\quad$ training, employment, human capital, older workers

Corresponding author:

Matteo Picchio

Department of Economics

Tilburg University

PO BOX 90153

5000 LE Tilburg

The Netherlands

E-mail: m.picchio@uvt.nl

\footnotetext{
* We acknowledge financial support for this research by Stichting Instituut GAK, through Reflect, the Research Institute for Flexicurity, Labor Market Dynamics and Social Cohesion at Tilburg University.
} 


\section{Introduction}

Active Labour Market Policies (ALMP) aim to increase employment rates by stimulating job finding rates and reducing job separation rates. In recessions ALMP are used to dampen the effects of the downturn in employment. In the recent crisis temporary shorter working hours arrangements, often in combination with increased training of workers, were used as instruments. Indeed several countries reported measures to provide training to existing workers at risk of job loss (OECD, 2010).

On-the-job training is an investment by individuals and firms which is aimed at upgrading individuals' human capital and which might pay back in terms of better labour market performances and higher productivity in the future. Training helps individuals to meet the needs of a changing economic and technological environment, enlarge the spectrum of competences, increase productivity, send good signals to employers, and thereby avoid unemployment events and return faster at work in case of job loss.

The question whether adult training affects labour market performances and productivity of individuals has been the core of substantial debates and research investigations. A strand of the literature analyses whether training programmes are tools to integrate the unemployed into the work force. Training programmes are found to have a modest or no effect on unemployment exit rates (Gerfin and Lechner, 2002; Andrén and Andrén, 2006; Crépon et al., 2007; Lechner et al., 2008; Lalive et al., 2008; Sianesi, 2008) and on wages (Heckman et al., 1999). Positive effects are instead found on the future employment stability (Crépon et al., 2007; Lechner et al., 2008) and Jones et al. (2009) show that training is significantly and positively associated with job satisfaction.

A similar branch of this literature has tried to understand how on-the-job training affects wages and other performance measures. Gritz (1993) concludes that participation in training improves the employment prospects, especially for women, the youth, and minorities. Bonnal et al. (1997) report that, in the private sector, on-the-job training increases the employment rates, especially for young workers. Bartel (1995) shows that, at firm level, wages and productivity are positively affected by on-the-job training. Finally, several other studies find that on-the-job training has a significantly positive impact on productivity (see, among others, Bartel, 1994; Barrett and O'Connell, 2001; Conti, 2005; Dearden et al., 2006).

In the Netherlands, previous evaluation studies have tried to infer the impact of different kind of training programmes on future employment prospects. Ridder (1986) distinguishes between training, recruitment, and employment programmes. He finds that especially women and ethnic minorities benefit from training programmes. Sanders and de Grip (2004) investigate whether training participation might affect low-skilled workers' 
firm-internal and firm-external mobility. They find that training increases firm-internal mobility, but it does not affect firm-external employability. Lastly, Pavlopoulos et al. (2009) analyse the effect of training on low pay mobility. They find that training increases the chances for upward wage mobility and therefore improves earnings prospects.

All in all, the effect of training on employment prospects is often found to be somewhat disappointing. Either training does not increase job finding rates significantly or even modest negative effects are found (see also Kluve (2010) for a recent overview study). Whereas the effect of training on job finding rates has been studied quite frequently, the effect on job separation rates is rarely investigated. ${ }^{1}$

Using data on the Netherlands from the European Community Household Panel (ECHP), we investigate whether firm-provided training enhances the probability of retaining workers into the workforce in the Netherlands. From the econometric viewpoint, it is challenging to disentangle the pure effect of training from the spurious one determined by individual unobserved heterogeneity. Unobserved heterogeneity might indeed jointly determine the likelihood of training participation and the labour market performances: motivation, labour market attachment, innate ability. Using semiparametric techniques to control for the endogeneity of training participations, we explicitly model the interrelated dynamics leading to training and determining the future employment prospects. We also take into account that there might be feedback from current employment shocks to individuals' future probability of receiving firm-provided training. As a result, we are able to estimate policy-relevant effects of on-the-job training participation on employment prospects later in life.

We find that in the Netherlands firm-provided training significantly improves future employability, i.e training leads to retaining. ${ }^{2}$ We also focus on the effect for older workers. As in many other European countries, the labour market position of older workers is cause for concern in the Netherlands, given that the demographic trends are causing an ageing of the workforce and that older workers' job separations are often a one-way street out of the labour force and into long-term unemployment. We find that older workers who receive training are more likely to remain employed. We suggest that additional onthe-job training of workers, especially older workers, can be influenced by government

\footnotetext{
${ }^{1}$ Using cross-country time series data on unemployment rates Boone and van Ours (2009) find that training has a significant negative effect on unemployment. They do not attribute this to the positive effect of training on the job finding rate but to the negative effect on the job separation rate. Training increases the human capital of participants and therefore the quality of their post-unemployment job increases, leading to lower job separation rates.

${ }^{2}$ In a companion paper, Picchio and van Ours (2011), we show that in the Netherlands firm-sponsored training is affected by labour market imperfections but not by product market competition. If labour mobility goes up employers are less willing to invest in training. If product market competition increases employer sponsored training is unaffected.
} 
policy, for example by providing the employers with age-specific subsidies to stimulate firm-provided training. Furthermore, an age-specific firing tax may persuade employers to train older workers, increasing thereby older workers' employability.

This paper is set up as follows. The data are described in Section 2. Section 3 formalizes the econometric model and clarifies the identification strategy. The estimation results are presented and discussed in Section 4. Section 5 concludes.

\section{Data Description}

The data used in this paper are from the 1994-2001 waves of the longitudinal dimension of the ECHP, a rotating panel survey based on harmonized methodology and definitions across several European countries. The ECHP contains nationally representative samples of households and covers a large set of of topics such as work, income, financial situation, housing, family, health, training and education, and social relations. We select data for the Netherlands, where the survey was annually conducted by Statistics Netherlands, under the coordination of Eurostat. The longitudinal ECHP data for the Netherlands comprise a number of individual records that range from 12,000 to 13,000 per year over the time window 1994-2001, for a total of 100,716 records.

From the original Dutch ECHP panel data, we lose the 1994 wave as information on training was not collected in 1994 in the Netherlands. We focus on prime age and older workers, i.e. workers who are older than 26 and younger than 64 years of age and who are either employee or not employed. Self-employed workers are deemed to be structurally different from employees and therefore are excluded from the sample. We drop observations with missing values in the variables used in the econometric analysis and we drop individuals that are not in the sample for at least three consecutive time periods between 1994 and 2001. The latter restriction is due to the fact that we estimate a dynamic model of order one with unobserved effects. Hence, one time period is lost because of the model dynamics. A further period is lost as we will use initial values to correct for initial conditions induced by the presence of unobserved effects.

After the application of these sample selection criteria, we have an unbalanced panel of 7,257 individuals, for a total of 33,348 individual-year observations, from 1996 until $2001 .^{3}$ Table 1 clarifies the structure of our data.

\footnotetext{
${ }^{3}$ Whe have an unbalanced panel due to attrition, missing information, and sample renewal for issues of representativeness over time. We assume that attrition and missing information are random. It would have been interesting to use more recent data. Unfortunately, it is not possible to use data the EU database on Statistics on Income and Living Conditions (SILC) as this database does not contain information about training.
} 
Table 1: The Structure of the Unbalanced Panel

\begin{tabular}{lrrrr}
\hline \hline \multirow{2}{*}{$\begin{array}{l}\text { Years of observation } \\
\text { (the initial year } t=0 \text { is not included) }\end{array}$} & $\begin{array}{r}\text { Individual records } \\
\text { Absolute } \\
\text { frequencies }\end{array}$ & $\begin{array}{r}\text { Relative } \\
\text { frequencies }\end{array}$ & $\begin{array}{r}\text { Total records } \\
\text { Absolute } \\
\text { frequencies }\end{array}$ & $\begin{array}{c}\text { Relative } \\
\text { frequencies }\end{array}$ \\
\hline $2000-2001$ & 496 & 0.070 & 992 & 0.030 \\
$1999-2000$ & 67 & 0.010 & 134 & 0.004 \\
$1999-2001$ & 407 & 0.057 & 1,221 & 0.037 \\
$1998-1999$ & 36 & 0.006 & 72 & 0.002 \\
$1998-2000$ & 44 & 0.006 & 132 & 0.004 \\
$1998-2001$ & 223 & 0.032 & 892 & 0.027 \\
$1997-1998$ & 53 & 0.009 & 106 & 0.003 \\
$1997-1999$ & 50 & 0.007 & 150 & 0.005 \\
$1997-2000$ & 32 & 0.005 & 128 & 0.004 \\
$1997-2001$ & 248 & 0.035 & 1,240 & 0.037 \\
$1996-1997$ & 514 & 0.073 & 1,028 & 0.031 \\
$1996-1997 / 2000-2001$ & 41 & 0.006 & 164 & 0.005 \\
$1996-1998$ & 522 & 0.072 & 1,566 & 0.047 \\
$1996-1999$ & 574 & 0.087 & 2,296 & 0.069 \\
$1996-2000$ & 473 & 0.074 & 2,365 & 0.071 \\
$1996-2001$ & 3,477 & 0.451 & 20,862 & 0.626 \\
\hline Total & $N=7,257$ & 1.000 & $N T=33,348$ & 1.000 \\
\hline
\end{tabular}

We are interested in whether and to what extent the employability of a worker - the probability of remaining employed - is affected by firm-provided training. The nonemployment indicator is constructed on the basis of the ILO definition of employment status. It is denoted by $y_{i t}$ and it is equal to 1 if individual $i$ is not in the workforce at time $t$ and 0 otherwise. The firm-provided training indicator $w_{i t}$ is instead equal to 1 if employee $i$ attended vocational education courses paid or organized by the firm since the beginning of the previous year and 0 otherwise. $^{4}$

Table 2 reports the probabilities of being out of the workforce conditional and unconditional of previous employment situation. The unconditional non-employment probability is $30.8 \%$ and it shows a strong persistence, possibly due to individual observed and unobserved heterogeneity: someone not employed at $t-1$ is almost 20 times as likely not to be employed at $t$ as someone employed at $t-1$. The non-employment probability is lower for those who attended some firm-provided training in the past than those who did not: $1.9 \%$ against $5.5 \%$. Note that the probability of attending firm-provided training courses seems to be strongly affected by the past employment condition. This might be due to individual observed and unobserved heterogeneity but it might also reflect feedback effects going from current shocks in the employment status to future probability of attending firm-provided training.

Table 3 displays the observed transitions between employment positions and, as ex-

\footnotetext{
${ }^{4}$ We build the non-employment indicator on the basis of variables PE003 and PE004 of the ECHP survey. The firm-provided training indicator is built on the basis of variables PT001 and PT017.
} 
Table 2: Raw Conditional and Unconditional Nonemployment Probabilities

\begin{tabular}{|c|c|c|c|c|}
\hline & \multicolumn{4}{|c|}{ Employment status at $t-1$} \\
\hline & Not employed & $\begin{array}{l}\text { Employed with } \\
\text { firm-provided training }\end{array}$ & $\begin{array}{l}\text { Employed without } \\
\text { firm-provided training }\end{array}$ & Total \\
\hline \multicolumn{5}{|l|}{ Employment status at $t$} \\
\hline Not employed & .883 & .019 & .055 & .308 \\
\hline Employed with firm-provided training & .004 & .285 & .043 & .041 \\
\hline Employed without firm-provided training & .113 & .696 & .902 & .651 \\
\hline Total & 1.000 & 1.000 & 1.000 & 1.000 \\
\hline Observations & 10,243 & 1,389 & 21,716 & 33,348 \\
\hline
\end{tabular}

pected, most of the individuals show a strong persistence in employment. The identification of the effect of training on employees' employability comes from observations out of the diagonal of this transition matrix.

Table 3: Absolute (Relative) Frequencies of Transitions between Labour Market Positions

\begin{tabular}{|c|c|c|c|c|}
\hline & \multicolumn{4}{|c|}{ Employment status at $t-1$} \\
\hline & Not employed & $\begin{array}{l}\text { Employed with } \\
\text { firm-provided training }\end{array}$ & $\begin{array}{l}\text { Employed without } \\
\text { firm-provided training }\end{array}$ & Total \\
\hline \multicolumn{5}{|l|}{ Employment status at $t$} \\
\hline Not employed & $9,048(.271)$ & $26(.001)$ & $1,194(.036)$ & $10,268(.308)$ \\
\hline Employed with firm-provided training & $36(.001)$ & $396(.014)$ & $931(.028)$ & $1,363(.041)$ \\
\hline Employed without firm-provided training & $1,159(.035)$ & $967(.029)$ & $19,591(.588)$ & $21,717(.651)$ \\
\hline Total & $10,243(.307)$ & $1,389(.042)$ & $21,716(.651)$ & $33,348(1.000)$ \\
\hline
\end{tabular}

Table 4 presents summary statistics of the outcome variables and of the variables used in the specification of the employment equation. We control for gender, education, age, years of potential work experience, health status, number of household components, presence of children in the household (younger than 12 years old), position in the family, and time indicators. ${ }^{5}$ The average age is about 43 years with 18 years of potential working experience. More than 53\% of the people in the sample are women, 54\% have a secondary degree, and more than $23 \%$ do not have a good health situation. On average each household has 3 members, while $35 \%$ of the sample has a child younger than 12 years of age in the household. Almost $86 \%$ of the people are living in a couple (married or unmarried).

Table 5 shows summary statistics of the covariates entering the training equation for employees. In this case further variables capturing job and employment characteristics are used to explain employees' probability of receiving firm-provided training: contract arrangement, part-time indicator, occupational dummies, job tenure, and sector and firm

\footnotetext{
${ }^{5}$ In the model specification we also included the interactions between gender and presence of children.
} 
Table 4: Summary Statistics of the Pooled Sample

\begin{tabular}{|c|c|c|c|c|}
\hline & Mean & Std. Dev. & Minimum & Maximum \\
\hline Female & .531 & .499 & .000 & 1.000 \\
\hline Education ISCED 5-7 & .205 & .404 & .000 & 1.000 \\
\hline Education ISCED 3 & .536 & .499 & .000 & 1.000 \\
\hline Education ISCED 0-2 & .259 & .438 & .000 & 1.000 \\
\hline Age & 43.498 & 10.047 & 26.000 & 64.000 \\
\hline Potential experience (years) & 18.102 & 13.662 & .000 & 52.000 \\
\hline Bad health $^{(\mathrm{b})}$ & .232 & .422 & .000 & 1.000 \\
\hline Number of household members & 3.019 & 1.287 & 1.000 & 8.000 \\
\hline Presence of kids younger than 12 & .354 & .478 & .000 & 1.000 \\
\hline Individual is cohabiting & .856 & .351 & .000 & 1.000 \\
\hline $\ln$ (household net income) $^{(\mathrm{b})}$ & 3.822 & 1.947 & .000 & 6.661 \\
\hline 1996 & .168 & .374 & .000 & 1.000 \\
\hline 1997 & .179 & .384 & .000 & 1.000 \\
\hline 1998 & .172 & .377 & .000 & 1.000 \\
\hline 1999 & .169 & .375 & .000 & 1.000 \\
\hline 2000 & .165 & .371 & .000 & 1.000 \\
\hline 2001 & .147 & .354 & .000 & 1.000 \\
\hline Observations $N T$ & \multicolumn{4}{|c|}{33,348} \\
\hline Number of individuals $N$ & \multicolumn{4}{|c|}{7,257} \\
\hline \multicolumn{5}{|c|}{$\begin{array}{l}\text { (a) We build the health indicator on the basis of variable PH001, which reports self- } \\
\text { perceived health. It is equal to one in case of fair, rather bad, or bad health conditions. } \\
\text { It is equal to zero in case of either good or very good health conditions. } \\
\text { (b) The household net income is computed from the variables HI100 and PI100. It does } \\
\text { not include the income of the corresponding individual and it is in constant prices } \\
\text { ( } 2000 \text { prices). It is deflated by using the Consumer Price Index (CPI), gathered by } \\
\text { Statistics Netherlands. }\end{array}$} \\
\hline
\end{tabular}

size indicators. About $82 \%$ of the employees have a permanent job and more than $30 \%$ work on a part-time basis. Almost half of the employees are high-skilled white collar workers, more than $71 \%$ work in the service sector, and more than $50 \%$ work in firms with more than 100 employees. More than $26 \%$ of the workers have a job in the public sector.

\section{Econometric Modelling}

In this Section we describe a multivariate discrete response model for panel data to investigate whether the employment probability is affected by participation in firm-provided training courses. There are reasons to suspect that the training indicator is a potentially endogenous human capital variable. First, there might be self-selection issues related to unobserved heterogeneity: time-invariant individual characteristics, unobservable by the econometrician, that jointly determine the probability of being at work and participating in training. Innate ability, intelligence, motivations, and labour market attachments are examples of such endowments that, if ignored, may lead to biased parameter estimates (Heckman, 1981; Hyslop, 1999). Second, there might be feedback effects from employ- 
Table 5: Summary Statistics of Employees

\begin{tabular}{|c|c|c|c|c|}
\hline & Mean & Std. Dev. & Minimum & Maximum \\
\hline Female & .459 & .498 & .000 & 1.000 \\
\hline Education ISCED 5-7 & .238 & .426 & .000 & 1.000 \\
\hline Education ISCED 3 & .538 & .499 & .000 & 1.000 \\
\hline Education ISCED 0-2 & .223 & .416 & .000 & 1.000 \\
\hline Age & 41.364 & 8.902 & 26.000 & 64.000 \\
\hline Potential experience (years) & 2.441 & 11.506 & .000 & 52.000 \\
\hline Bad health & .166 & .372 & .000 & 1.000 \\
\hline Number of household members & 3.055 & 1.267 & 1.000 & 8.000 \\
\hline Presence of kids younger than 12 & .375 & .484 & .000 & 1.000 \\
\hline Individual is cohabiting & .860 & .347 & .000 & 1.000 \\
\hline $\ln$ (household net income) & 3.785 & 1.922 & .000 & 6.561 \\
\hline 1996 & .163 & .370 & .000 & 1.000 \\
\hline 1997 & .174 & .379 & .000 & 1.000 \\
\hline 1998 & .171 & .376 & .000 & 1.000 \\
\hline 1999 & .170 & .376 & .000 & 1.000 \\
\hline 2000 & .170 & .376 & .000 & 1.000 \\
\hline 2001 & .151 & .358 & .000 & 1.000 \\
\hline Permanent contract & .818 & .386 & .000 & 1.000 \\
\hline Part-time job & .301 & .459 & .000 & 1.000 \\
\hline Blue collar worker ${ }^{(a)}$ & .257 & .437 & .000 & 1.000 \\
\hline Low-skilled white collar worker ${ }^{(\mathrm{a})}$ & .246 & .431 & .000 & 1.000 \\
\hline High-skilled white collar worker ${ }^{(a)}$ & .497 & .500 & .000 & 1.000 \\
\hline Agriculture & .012 & .110 & .000 & 1.000 \\
\hline Industry & .195 & .396 & .000 & 1.000 \\
\hline Services & .711 & .453 & .000 & 1.000 \\
\hline Unknown sector & .082 & .274 & .000 & 1.000 \\
\hline Public employment & .261 & .439 & .000 & 1.000 \\
\hline Unknown job tenure & .140 & .347 & .000 & 1.000 \\
\hline Job tenure $0-4$ years & .301 & .459 & .000 & 1.000 \\
\hline Job tenure $5-9$ years & .184 & .387 & .000 & 1.000 \\
\hline Job tenure $10-14$ years & .127 & .332 & .000 & 1.000 \\
\hline Job tenure 15 years or more & .248 & .432 & .000 & 1.000 \\
\hline Firm size is not applicable & .145 & .353 & .000 & 1.000 \\
\hline Firm size 0-4 employees & .033 & .178 & .000 & 1.000 \\
\hline Firm size 5-19 employees & .117 & .321 & .000 & 1.000 \\
\hline Firm size 20-49 employees & .108 & .310 & .000 & 1.000 \\
\hline Firm size 50-99 employees & .089 & .284 & .000 & 1.000 \\
\hline Firm size 100-499 employees & .222 & .416 & .000 & 1.000 \\
\hline Firm size 500 employees or more & .286 & .452 & .000 & 1.000 \\
\hline Observations $N T$ & \multicolumn{4}{|c|}{23,080} \\
\hline Number of individuals $N$ & \multicolumn{4}{|c|}{5,609} \\
\hline
\end{tabular}

(a) We built the occupational dummies on the basis of variable PE006C. We define as high-skilled white collars those workers who reported to be legislators, senior officers, managers, professionals, technicians, or associate professionals. We define as lowskilled white collars those workers we were clerks, service workers, or shop/market sales workers. We define as blue collars those workers employed as skilled agricultural or fishery workers, craft and related trades workers, plant and machine operators and assemblers, or elementary occupations. 
ment status to future training participation, i.e. shocks in the employment status affecting future probabilities of training participation. There are indeed reasons to expect that future participation in a training programme can be correlated to the recent labour market history (Bassi, 1984; Ham and LaLonde, 1996). For instance, individuals with a negative transitory shock in the employment probability can be seen as less reliable and less attached to the labour market and, therefore, employers might be less willing to provide them with training courses. Alternatively, individuals that involuntarily exit employment might change their behaviour and invest in their own human capital.

We use a discrete response unobserved effects model for panel data that can deal with these endogeneity issues. We jointly model the employment status and, in case of employment $\left(y_{i t}=0\right)$, the firm-provided training participation. The model is designed with a dynamic recursive structure. The current employment status depends on the past employment condition and upon firm-provided training received in the past. Similarly, for those who are at work, the probability of receiving firm-provided training depends on the previous employment condition and past training participation. More in detail, the interrelated dynamics between employment situation and training participation are specified using a panel data bivariate unobserved effects probit model, i.e. for $i=1, \ldots, N$ and $t=1, \ldots, T$

$$
\begin{aligned}
y_{i t} & =1\left[y_{i t-1} \delta_{1}+w_{i t-1} \gamma_{1}+\mathbf{x}_{i t}^{\prime} \beta_{1}+c_{1 i}+u_{1 i t}>0\right] \\
w_{i t} & =1\left[y_{i t-1} \delta_{2}+w_{i t-1} \gamma_{2}+\mathbf{z}_{i t}^{\prime} \beta_{2}+c_{2 i}+u_{2 i t}>0\right] \quad \text { if } y_{i t}=0,
\end{aligned}
$$

where:

- $1[\cdot]$ is the indicator function;

- $\mathbf{x}_{i t}$ is the vector of strictly exogenous covariates explaining the employment status and $\beta_{1}$ is the conformable vector of parameters;

- $\mathbf{z}_{i t}$ is the vector of strictly exogenous covariates explaining training participation and $\beta_{2}$ is the conformable vector of parameters;

- $\left(c_{1 i}, c_{2 i}\right)$ is the time-invariant individual heterogeneity characterized by joint distribution with, a priori, unrestricted correlation structure;

- $u_{1 i t}$ and $u_{2 i t}$ are iid errors with standard normal distribution.

This model is a modified version of the one in Alessie et al. (2004) and similar to that used by Stewart (2007) to analyse the interrelated dynamics of unemployment and low-wage employment and by Picchio (2008) to study the stepping-stone effect of temporary jobs.

Equation (1) shows that in each time period the probability of individual $i$ of being out of the workforce at time $t$ is determined by a vector of observed characteristics, $\mathbf{x}_{i t}$, 
by unobserved heterogeneity, $c_{1 i}$, and by the previous employment situation (employment without training, employment with training, or nonemployment). The previous employment situation is described by the values taken by $y_{i t-1}$, equal to one in case of nonemployment, and by the values taken by $w_{i t-1}$, equal to one in case of employment with firm-provided training. The coefficients $\delta_{1}$ and $\gamma_{1}$ are of particular interest. The former is the effect of previous nonemployment on the current employability with respect to the case of employment without firm-provided training. The latter is the effect of previous employment with firm-provided training on the current employability with respect to the case of employment without firm-provided training.

For those who are at work, equation (2) describes the process determining the probability of receiving firm-provided training. This is affected by a set of observed characteristics, $\mathbf{z}_{i t}$, by unobservables, $c_{2 i}$, and by past employment situation. The coefficient $\gamma_{2}$ is the effect of past employment with training, rather than without training, on the current probability of receiving training.

Although the $u_{1 i t}$ and the $u_{2 i t}$ are assumed iid, the composite error terms will be correlated over time due to the presence of the individual fixed effects $c_{1 i}$ and $c_{2 i}$. They will also be correlated across equations due to unrestricted correlation structure between $c_{1 i}$ and $c_{2 i}$. In other words, unconditional on $c_{1 i}$ and $c_{2 i}$ the nonemployment equation is correlated to the training equation, but once we condition on these unobserved factors (and on a set of observed characteristics) the two processes are independent. Note that if the two equations are independent, $w_{i t-1}$ is weakly endogenous in the employment equation and equation (1) could be estimated in a univariate framework with predetermined regressors.

\subsection{Unobserved Heterogeneity and Initial Conditions}

The dynamic unobserved effects probit model in equations (1) and (2) can distinguish between spurious effects determined by unobserved heterogeneity and the true effect of lagged variables (state dependence). However, the presence of unobserved heterogeneity generates two problems that must be faced when estimating such a non-linear model: first, how to get rid of the fixed effects $c_{1 i}$ and $c_{2 i}$ as it is well known that they cannot be treated as parameters to be estimated due to the incidental parameters problem (e.g. Heckman, 1981); second, the initial conditions problems that arise in a dynamic model when the initial observations of the outcome variables are correlated to the unobserved heterogeneity.

We solve for these problems by mixing parametric and semiparametric assumptions. First, we allow for dependence between observed and unobserved characteristics by using a Mundlak (1978) version of Chamberlain's (1984) approach. Second, the initial 
conditions problem is addressed by using Wooldridge's (2005) approach. ${ }^{6}$ Formally, the parametric specification of the unobserved heterogeneity terms is assumed to be,

$$
\begin{aligned}
& c_{1 i}=\overline{\mathbf{x}}_{i}^{\prime} \alpha_{1}+y_{i 0} \theta_{1}+w_{i 0} \psi_{1}+v_{1 i}, \\
& c_{2 i}=\overline{\mathbf{z}}_{i}^{\prime} \alpha_{2}+y_{i 0} \theta_{2}+w_{i 0} \psi_{2}+v_{2 i}
\end{aligned}
$$

where $\overline{\mathbf{x}}_{i}$ and $\overline{\mathbf{z}}_{i}$ are the individual time averages of respectively $\mathbf{x}_{i t}$ and $\mathbf{z}_{i t}$, and $y_{i 0}$ and $w_{i 0}$ are the realizations of the outcome variables at the date of entry into our sample. The term $\mathbf{v}_{i} \equiv\left(v_{1 i}, v_{2 i}\right)$ is residual unobserved heterogeneity and it is assumed to be independent of observed characteristics. The unobserved time-invariant factors are allowed to be crosscorrelated, so as to capture cross-equation correlation. In our preferred specification, we avoid too strict parametric assumptions on the distribution of the random unobserved heterogeneity. We follow Heckman and Singer (1984) and assume that the vector $\mathbf{v}_{i}$ is a random draw from a discrete distribution function. More in detail, we assume that $v_{1 i}$ and $v_{2 i}$ have two points of support each with the following four probabilities:

$$
\begin{array}{ll}
p^{1} \equiv \operatorname{Pr}\left(v_{1}=v_{1 i}^{1}, v_{2}=v_{2 i}^{1}\right) & p^{2} \equiv \operatorname{Pr}\left(v_{1}=v_{1 i}^{2}, v_{2}=v_{2 i}^{1}\right) \\
p^{3} \equiv \operatorname{Pr}\left(v_{1}=v_{1 i}^{1}, v_{2}=v_{2 i}^{2}\right) & p^{4} \equiv \operatorname{Pr}\left(v_{1}=v_{1 i}^{2}, v_{2}=v_{2 i}^{2}\right)
\end{array}
$$

The probabilities associated to the mass points are specified as logistic transforms:

$$
p^{m}=\frac{\exp \left(\lambda_{m}\right)}{\sum_{r=1}^{4} \exp \left(\lambda_{r}\right)} \quad \text { with } \quad \lambda_{4}=0 .
$$

Note that $v_{1}$ and $v_{2}$ are independent if and only if $p^{1} p^{4}=p^{2} p^{3}$ (see van den Berg and Lindeboom, 1998; van den Berg and Ridder, 1994). This makes it easy to test whether the nonemployment and training equations are independent. Furthermore, it can be shown that the correlation $\rho_{v}$ between $v_{1}$ and $v_{2}$ is given by

$$
\rho_{v}=\frac{p^{1} p^{4}-p^{2} p^{3}}{\sqrt{\left(p^{1}+p^{3}\right)\left(p^{2}+p^{4}\right)\left(p^{1}+p^{2}\right)\left(p^{3}+p^{4}\right)}} .
$$

\footnotetext{
${ }^{6}$ An alternative correction of the initial conditions problem is in Heckman (1981) and it is based on a separate formulation of the processes leading to the first realizations of the outcome variables, in order to get an approximation of the conditional distribution of the initial conditions. In this study, we prefer Wooldridge's (2005) approach because the true processes are already ongoing when the first observations are recorded and they are likely to be generated in the same way as later observations. Moreover, Wooldridge's (2005) approach is computationally less demanding.
} 


\subsection{The Likelihood Function}

Our assumptions with respect to the individual heterogeneity distribution and on the initial conditions allow us to rewrite the model in equations (1) and (2) as

$$
\begin{aligned}
y_{i t} & =1\left[y_{i t-1} \delta_{1}+w_{i t-1} \gamma_{1}+\mathbf{x}_{i t}^{\prime} \beta_{1}+\overline{\mathbf{x}}_{i}^{\prime} \alpha_{1}+y_{i 0} \theta_{1}+w_{i 0} \psi_{1}+v_{1 i}+u_{1 i t}>0\right] \\
w_{i t} & =1\left[y_{i t-1} \delta_{2}+w_{i t-1} \gamma_{2}+\mathbf{z}_{i t}^{\prime} \beta_{2}+\overline{\mathbf{z}}_{i}^{\prime} \alpha_{2}+y_{i 0} \theta_{2}+w_{i 0} \psi_{2}+v_{2 i}+u_{2 i t}>0\right] \text { if } y_{i t}=0 .
\end{aligned}
$$

Since the unobserved heterogeneity term $\mathbf{v}_{i}$ is not observed and is a random term from a bivariate distribution, it can be integrated out when the model is estimated by maximum likelihood (ML). The probability masses and the location of the points of support of the discrete unobserved heterogeneity distribution are estimated by ML jointly with all the other parameters. On the basis of model in equations (5) and (6) and the assumptions on the distribution of $\mathbf{v}_{i}$, the contribution to the likelihood function of individual $i$ is given by

$$
\begin{aligned}
\mathscr{L}_{i}=\sum_{m=1}^{4} p^{m} \prod_{t=1}^{T} \Phi\left[\left(2 y_{i t}-1\right)\left(y_{i t-1} \delta_{1}+w_{i t-1} \gamma_{1}+\mathbf{x}_{i t}^{\prime} \beta_{1}+\overline{\mathbf{x}}_{i}^{\prime} \alpha_{1}+y_{i 0} \theta_{1}+w_{i 0} \psi_{1}+v_{1 i}^{m}\right)\right] \\
\times \Phi\left[\left(2 w_{i t}-1\right)\left(y_{i t-1} \delta_{2}+w_{i t-1} \gamma_{2}+\mathbf{z}_{i t}^{\prime} \beta_{2}+\overline{\mathbf{z}}_{i}^{\prime} \alpha_{2}+y_{i 0} \theta_{2}+w_{i 0} \psi_{2}+v_{2 i}^{m}\right)\right]^{\left(1-y_{i t}\right)}
\end{aligned}
$$

where $\Phi$ denotes the cumulative distribution function of the standard normal distribution. The log-likelihood function is the sum over the sample of the log of the individual likelihood contribution, i.e. $\ell=\sum_{i=1}^{N} \ln \left(\mathscr{L}_{i}\right)^{7}$

\section{Estimation Results}

\subsection{Dynamic Unobserved Effects Probit}

Tables 6 and 7 display the estimation results of four specifications of the dynamic unobserved effects probit model. The first specification is the benchmark model as described in Section 3 and our preferred specification.

In the second specification, job characteristics are not included among the explanatory variables of the training equation. As job characteristics may not be strictly exogenous, we check thereby whether the results are sensitive to their (in)exclusion. As shown by Table 6, the exclusion of job characteristics from the training equation has little effect on the estimation results. Our preferred specification is however the first one, since job

\footnotetext{
${ }^{7}$ We used the Matlab minimizer fminunc with analytic first derivatives to obtain the ML estimates.
} 
characteristics can help to control for time-varying factors (e.g. the quality of the job match) which might be correlated to the probability of receiving firm-provided training and, at the same time, to the probability of keeping the job.

In the third specification, we change the assumptions about the distribution of the unobserved heterogeneity term $\mathbf{v}_{i}$ and we impose a bivariate normal distribution with zero mean and correlation $\rho_{v}$, instead of a discrete distribution. We find that specification 1 is to be preferred according to likelihood criteria, e.g. the Akaike Information Criterion (AIC) reported at the bottom of Tables 6 and 7. While in specification 1 we can confidently reject the null hypothesis of independent equations, this is not the case in specification 3. As a matter of fact, the estimation results in specification 4, a single-equation model for employment status, are in line with those of specification 3. This suggests that imposing too strict parametric assumptions on the unobserved heterogeneity term $\mathbf{v}_{i}$ results in model misspecification and biased estimation results.

In the upper panel of Tables 6 and 7 we report usual coefficient estimates. In the second panel we report instead estimated predicted probabilities and average partial effects (APEs) that are of focal interest in this paper. They are aimed at quantifying the size of the effects under analysis. There are different ways in which the marginal effect of $y_{i t-1}$ and $w_{i t-1}$ on the nonemployment probability can be estimated in a dynamic unobserved effects probit model. At the sample mean of the exogenous regressor $(\overline{\mathbf{x}})$, we define:

- $\pi_{1}$ as the probability of being currently nonemployed conditional on employment without firm-provided training in the previous period;

- $\pi_{2}$ as the probability of being currently nonemployed conditional on employment with firm-provided training in the previous period;

- $\pi_{3}$ as the probability of being currently nonemployed conditional on nonemployment in the previous period.

Consistent estimators of these probabilities are:

$$
\begin{aligned}
& \widehat{\pi}_{1}=\frac{1}{N} \sum_{i=1}^{N} \sum_{m=1,2} \widehat{p}^{m} \Phi\left(\quad \overline{\mathbf{x}}^{\prime} \widehat{\beta}_{1}+\overline{\mathbf{x}}_{i}^{\prime} \widehat{\alpha}_{1}+y_{i 0} \widehat{\theta}_{1}+w_{i 0} \widehat{\psi}_{1}+\widehat{v}_{1 i}^{m}\right) ; \\
& \widehat{\pi}_{2}=\frac{1}{N} \sum_{i=1}^{N} \sum_{m=1,2} \widehat{p}^{m} \Phi\left(\widehat{\gamma}_{1}+\overline{\mathbf{x}}^{\prime} \widehat{\beta}_{1}+\overline{\mathbf{x}}_{i}^{\prime} \widehat{\alpha}_{1}+y_{i 0} \widehat{\theta}_{1}+w_{i 0} \widehat{\psi}_{1}+\widehat{v}_{1 i}^{m}\right) ; \\
& \widehat{\pi}_{3}=\frac{1}{N} \sum_{i=1}^{N} \sum_{m=1,2} \widehat{p}^{m} \Phi\left(\widehat{\delta}_{1}+\overline{\mathbf{x}}^{\prime} \widehat{\beta}_{1}+\overline{\mathbf{x}}_{i}^{\prime} \widehat{\alpha}_{1}+y_{i 0} \widehat{\theta}_{1}+w_{i 0} \widehat{\psi}_{1}+\widehat{v}_{1 i}^{m}\right) .
\end{aligned}
$$


We obtain the APEs by taking the difference between these quantities. ${ }^{8}$ Two APEs are particular useful for discussion: $\widehat{\pi}_{2}-\widehat{\pi}_{1}$ and $\widehat{\pi}_{2}-\widehat{\pi}_{3}$. The former measures the effect on the nonemployment probability of previous employment with firm-provided training rather than without firm-provided training. It is a measure of whether and to what extent firm-provided training boosts employees's chances to be retained in the workforce in the future. The latter is the effect on the nonemployment probability of previous employment with firm-provided training rather than previous nonemployment.

The benchmark model (specification 1 in Table 6) gives an APE of past employment with training, rather than employment without training, of -0.052 , statistically significant at the $1 \%$ confidence level. An employee with a given set of observed and unobserved characteristics is 5.2 percentage points less likely to be out of the workforce at $t$ if she had been employed with training at $t-1$ than if she had been employed without training at $t-1$. It is a quite large effect: the nonemployment probability decreases from 32.6 percentage points to 27.4 percentage points, i.e. by $16 \%$. As shown in Table 2, the corresponding figure from raw data is $65.5 \%$. This points out that more than three fourths of the raw effect of firm-provided training on employability is spurious and determined by observed and unobserved characteristics.

Three other issues are worth mentioning. First, it is clear from the statistics in Table 2 that there is a sizeable persistence in nonemployment: people who were out of the workforce at $t-1$ are about 46 (16) times more likely to be nonemployed at $t$ than people who were employed with (without) firm-provided training at $t-1$. These figures become much smaller but still sizeable when we get rid of spurious state dependence induced by individual heterogeneity (observed and unobserved): an individual is "only" about twice as likely to be nonemployed at $t$ if she had been out of the workforce at $t-1$ as if she had been employed with or without training at $t-1 .^{9}$

Second, the estimated correlation between the unobserved determinants of nonemployment and training is negative, -0.665 , and highly significant. Unobserved characteristics, like ability, motivation, and attachment to work, affect positively the probability of receiving firm-provided training and negatively the probability of being out of the workforce.

Third, in specification 3 we fail to capture the cross-equation correlation induced by unobserved heterogeneity, probably because of too strict parametric assumptions on its

\footnotetext{
${ }^{8}$ Standard errors of the predicted probabilities and of the APEs are estimated by bootstrapping the results (individual-cluster bootstrap with replacement).

${ }^{9}$ More in detail, with raw data the nonemployment probability decreases from $88.3 \%$ to $1.9 \%$ in case of employment with training and to $5.5 \%$ in case of employment without training. Once we net out spurious state dependence, the nonemployment probability decreases from $52 \%$ to $27.4 \%$ in case of employment with training and to $32.6 \%$ in case of employment without training.
} 
Table 6: Dynamic Unobserved Effects Probit Model

\begin{tabular}{|c|c|c|c|c|c|c|c|c|c|c|c|c|}
\hline \multirow[b]{3}{*}{ Variable } & \multicolumn{6}{|c|}{ Specification 1} & \multicolumn{6}{|c|}{ Specification 2} \\
\hline & \multicolumn{3}{|c|}{$\begin{array}{c}\text { Nonemployment } \\
\text { equation }\end{array}$} & \multicolumn{3}{|c|}{$\begin{array}{l}\text { Firm-provided } \\
\text { training equation }\end{array}$} & \multicolumn{3}{|c|}{$\begin{array}{c}\text { Nonemployment } \\
\text { equation }\end{array}$} & \multicolumn{3}{|c|}{$\begin{array}{l}\text { Firm-provided } \\
\text { training equation }\end{array}$} \\
\hline & Coeff. & & S.E. & Coeff. & & S.E. & Coeff. & & S.E. & Coeff. & & S.E. \\
\hline Nonemployment $_{t-1}$ & 1.715 & **** & .033 & -.093 & & .101 & 1.717 & *** & .033 & -.156 & & .099 \\
\hline Firm-provided training $t_{t-1}$ & -.546 & $* * *$ & .115 & .738 & $* * *$ & .060 & -.281 & $* *$ & .111 & .756 & $* * *$ & .059 \\
\hline Female & .205 & $* * *$ & .044 & -.010 & & .051 & .211 & $* * *$ & .044 & -.056 & & .045 \\
\hline \multicolumn{13}{|c|}{ Education - Reference: Education ISCED 0-2 } \\
\hline Education ISCED 5-7 & -.270 & $* * *$ & .046 & -.113 & $*$ & .059 & -.266 & $* * *$ & .046 & .086 & & .053 \\
\hline Education ISCD 3 & -.206 & $* * *$ & .035 & .001 & & .046 & -.205 & $* * *$ & .035 & .057 & & .044 \\
\hline Age/10 & -1.732 & $* * *$ & .154 & .171 & & .259 & -1.759 & $* * *$ & .154 & .243 & & .254 \\
\hline Age squared/1000 & 2.408 & $* * *$ & .177 & -.418 & & .336 & 2.441 & $* * *$ & .177 & -.570 & $*$ & .332 \\
\hline Work experience/10 & 1.285 & $* * *$ & .185 & -.279 & & .340 & 1.285 & $* * *$ & .185 & -.635 & $* *$ & .321 \\
\hline Work exper. squared/1000 & .073 & $*$ & .037 & -.013 & & .061 & .077 & $* *$ & .037 & -.007 & & .059 \\
\hline Bad health & .218 & $* * *$ & .042 & .062 & & .062 & .218 & $* * *$ & .042 & .050 & & .060 \\
\hline No. household members & .069 & $*$ & .040 & .006 & & .051 & .071 & $*$ & .040 & -.030 & & .050 \\
\hline Kids $<12$ years & .227 & $*$ & .127 & .012 & & .108 & .234 & $*$ & .126 & .001 & & .104 \\
\hline Kids $<12$ years $*$ Female & .165 & & .146 & -.311 & $* *$ & .155 & .156 & & .146 & -.433 & $* * *$ & .150 \\
\hline Living in a couple & -.493 & $* * *$ & .136 & .049 & & .139 & -.498 & $* * *$ & .136 & .098 & & .137 \\
\hline $\ln$ (household net income) & .072 & $* * *$ & .015 & -.040 & $* *$ & .020 & .071 & $* * *$ & .015 & -.041 & $* *$ & .019 \\
\hline Permanent contract & - & & - & .072 & & .062 & - & & - & - & & - \\
\hline Part-time job & - & & - & -.310 & $* * *$ & .083 & - & & - & - & & - \\
\hline Public employment & - & & - & .114 & & .071 & - & & - & - & & - \\
\hline \multicolumn{13}{|c|}{ Occupation indicators - Reference: High-skilled white collar worker } \\
\hline Blue collar & - & & - & -.215 & $* *$ & .085 & - & & - & - & & - \\
\hline Low-skilled white collar & - & & - & -.202 & $* * *$ & .063 & - & & - & - & & - \\
\hline \multicolumn{13}{|c|}{ Sectoral indicators - Reference: Services } \\
\hline Agriculture & - & & - & .041 & & .384 & - & & - & - & & - \\
\hline Industry & - & & - & -.224 & $* * *$ & .086 & - & & - & - & & - \\
\hline Unknown sector & - & & - & -.322 & $* * *$ & .081 & - & & - & - & & - \\
\hline \multicolumn{13}{|c|}{ Job tenure indicators - Reference: $0-4$ years } \\
\hline Unknown & - & & - & -.312 & $* *$ & .144 & - & & - & - & & - \\
\hline $5-9$ years & - & & - & -.269 & $* * *$ & .065 & - & & - & - & & - \\
\hline $10-14$ years & - & & - & -.227 & $* *$ & .091 & - & & - & - & & - \\
\hline 15 years or more & - & & - & -.267 & $* *$ & .121 & - & & - & - & & - \\
\hline \multicolumn{13}{|c|}{ Initial conditions and unobserved heterogeneity support points } \\
\hline Nonemployment $_{0}$ & 1.384 & $* * *$ & .075 & .505 & $* * *$ & .115 & 1.407 & $* * *$ & .077 & .004 & & .085 \\
\hline Firm-provided training 0 & -.059 & & .105 & .357 & $* * *$ & .069 & -.144 & & .102 & .449 & $* * *$ & .071 \\
\hline$\widehat{v}_{i}^{1}$ & 1.998 & $* * *$ & 6.571 & -2.199 & $* * *$ & .482 & 2.042 & $* * *$ & .304 & -2.067 & $* * *$ & .477 \\
\hline$\widehat{v}_{j}^{2}$ & .539 & $*$ & 1.812 & -1.426 & $* * *$ & .497 & .560 & $*$ & .297 & -1.284 & $* * *$ & .472 \\
\hline$\widehat{\rho}_{v}^{j}$ & -.665 & $* * *$ & .208 & & & & .114 & & .144 & & & \\
\hline Predicted probability $\widehat{p}_{1}$ & .326 & *** & .015 & - & & - & .325 & $* * *$ & 0.017 & - & & - \\
\hline Predicted probability $\widehat{p}_{2}$ & .274 & $* * *$ & .021 & - & & - & .297 & $* * *$ & 0.022 & - & & - \\
\hline Predicted probability $\widehat{p}_{3}$ & .520 & $* * *$ & .009 & - & & - & .518 & $* * *$ & 0.009 & - & & - \\
\hline APE: $\widehat{p}_{2}-\widehat{p}_{1}$ & -.052 & $* * *$ & .012 & - & & - & -.028 & $* * *$ & 0.012 & - & & - \\
\hline APE: $\widehat{p}_{2}-\widehat{p}_{3}$ & -.247 & $* * *$ & .025 & - & & - & -.221 & $* * *$ & 0.025 & - & & - \\
\hline$N T(N)$ & \multicolumn{6}{|c|}{$33,348(7,275)$} & \multicolumn{6}{|c|}{$33,348(7,275)$} \\
\hline Log-likelihood & \multicolumn{6}{|c|}{$-11,812.7$} & \multicolumn{6}{|c|}{$-11,946.7$} \\
\hline No. of parameters & \multicolumn{6}{|c|}{103} & \multicolumn{6}{|c|}{67} \\
\hline Pseudo- $R^{2}$ & & & .5 & & & & & & .5 & & & \\
\hline Test of independent eq. & & & $=5.32 p$ & alue $=.02$ & & & & & $=.94 p-$ & alue $=.332$ & & \\
\hline
\end{tabular}


Table 7: Dynamic Unobserved Effects Probit Model

\begin{tabular}{|c|c|c|c|c|c|c|c|c|c|}
\hline \multirow[b]{3}{*}{ Variable } & \multicolumn{6}{|c|}{ Specification 3} & \multirow{2}{*}{\multicolumn{3}{|c|}{$\begin{array}{c}\text { Specification } 4 \\
\begin{array}{c}\text { Nonemployment } \\
\text { equation }\end{array}\end{array}$}} \\
\hline & \multicolumn{3}{|c|}{$\begin{array}{c}\text { Nonemployment } \\
\text { equation }\end{array}$} & \multicolumn{3}{|c|}{$\begin{array}{l}\text { Firm-provided } \\
\text { training equation }\end{array}$} & & & \\
\hline & Coeff. & & S.E. & Coeff. & & S.E. & Coeff. & & S.E. \\
\hline Nonemployment $_{t-1}$ & 2.155 & $* * *$ & .035 & -.254 & & .240 & 2.155 & $* * *$ & .035 \\
\hline Firm-provided training ${ }_{t-1}$ & -.311 & $* * *$ & .086 & .925 & $* * *$ & .045 & -.304 & $* * *$ & .085 \\
\hline Female & .143 & $* * *$ & .033 & -.020 & & .046 & .144 & $* * *$ & .033 \\
\hline \multicolumn{10}{|c|}{ Education - Reference: Education ISCED 0-2 } \\
\hline Education ISCED 5-7 & -.199 & $* * *$ & .037 & -.087 & $*$ & .048 & -.199 & $* * *$ & .038 \\
\hline Education ISCD 3 & -.143 & $* * *$ & .029 & .016 & & .039 & -.143 & $* * *$ & .029 \\
\hline Age/10 & -1.299 & $* * *$ & .135 & .292 & & .224 & -1.304 & $* * *$ & .135 \\
\hline Age squared/1000 & 1.827 & $* * *$ & .161 & -.592 & $* *$ & .290 & 1.832 & $* * *$ & .160 \\
\hline Work experience/10 & 1.300 & $* * *$ & .205 & -.372 & & .276 & 1.296 & $* * *$ & .205 \\
\hline Work exper. squared/1000 & -.048 & & .031 & -.016 & & .051 & -.048 & & .031 \\
\hline Bad health & .182 & $* * *$ & .041 & .050 & & .058 & .181 & $* * *$ & .042 \\
\hline No. household members & .051 & & .035 & .001 & & .045 & .050 & & .035 \\
\hline Kids $<12$ years & .171 & $* *$ & .083 & .000 & & .095 & .173 & $* *$ & .084 \\
\hline Kids $<12$ years $*$ Female & .123 & & .111 & -.309 & $* *$ & .137 & .120 & & .111 \\
\hline Living in a couple & -.398 & $* * *$ & .101 & .080 & & .111 & -.398 & $* * *$ & .101 \\
\hline $\ln$ (household net income) & .064 & $* * *$ & .015 & -.038 & $* *$ & .017 & .064 & $* * *$ & .015 \\
\hline Permanent contract & - & & - & .109 & & .071 & - & & - \\
\hline Part-time job & - & & - & -.275 & $* * *$ & .077 & - & & - \\
\hline Public employment & - & & - & .120 & $*$ & .070 & - & & - \\
\hline \multicolumn{10}{|c|}{ Occupation indicators - Reference: High-skilled white collar worker } \\
\hline Blue collar & - & & - & -.190 & $* *$ & .074 & - & & - \\
\hline Low-skilled white collar & - & & - & -.180 & $* * *$ & .065 & - & & - \\
\hline \multicolumn{10}{|c|}{ Sectoral indicators - Reference: Services } \\
\hline Agriculture & - & & - & .070 & & .320 & - & & - \\
\hline Industry & - & & - & -.188 & $* *$ & .087 & - & & - \\
\hline Unknown sector & - & & - & -.289 & $* * *$ & .078 & - & & - \\
\hline \multicolumn{10}{|c|}{ Job tenure indicators - Reference: $0-4$ years } \\
\hline Unknown & - & & - & -.223 & $*$ & .134 & - & & - \\
\hline $5-9$ years & - & & - & -.244 & $* * *$ & .058 & - & & - \\
\hline $10-14$ years & - & & - & -.187 & $* *$ & .084 & - & & - \\
\hline 15 years or more & - & & - & -.205 & $*$ & .112 & - & & - \\
\hline Constant & .597 & $* *$ & .266 & -2.048 & $* * *$ & .407 & 607 & $* *$ & .266 \\
\hline \multicolumn{10}{|c|}{ Initial conditions and unobserved heterogeneity correlation } \\
\hline Nonemployment $_{0}$ & .560 & $* * *$ & .036 & .140 & $*$ & .074 & .559 & $* * *$ & .036 \\
\hline Firm-provided training 0 & -.097 & & .084 & .248 & $* * *$ & .053 & -.096 & & .084 \\
\hline$\widehat{\rho}_{v}$ & -.230 & & .235 & & & & - & & - \\
\hline Predicted probability $\widehat{p}_{1}$ & .260 & $* * *$ & . & - & & - & .260 & $* * *$ & .021 \\
\hline Predicted probability $\widehat{p}_{2}$ & .221 & $* * *$ & . & - & & - & .221 & $* * *$ & .026 \\
\hline Predicted probability $\widehat{p}_{3}$ & .603 & $* * *$ & . & - & & - & .604 & $* * *$ & .016 \\
\hline APE: $\widehat{p}_{2}-\widehat{p}_{1}$ & -.040 & $* * *$ & . & - & & - & -.039 & $* * *$ & .011 \\
\hline APE: $\widehat{p}_{2}-\widehat{p}_{3}$ & -.383 & $* * *$ & . & - & & - & -.383 & $* * *$ & .040 \\
\hline$N T(N)$ & \multicolumn{6}{|c|}{$33,348(7,275)$} & \multicolumn{3}{|c|}{$33,348(7,275)$} \\
\hline Log-likelihood & \multicolumn{6}{|c|}{$-11,937.8$} & \multicolumn{3}{|c|}{$-7,441.8$} \\
\hline No. of parameters & \multicolumn{6}{|c|}{99} & \multicolumn{3}{|c|}{31} \\
\hline Pseudo- $R^{2}$ & \multicolumn{6}{|c|}{.537} & \multicolumn{3}{|c|}{.639} \\
\hline Test of independent eq. & \multicolumn{6}{|c|}{$\chi_{1}^{2}=.36 p$-value $=.843$} & \multicolumn{3}{|c|}{-} \\
\hline
\end{tabular}

Notes: * Significant at $10 \%$ level; ** significant at $5 \%$ level; $* * *$ significant at $1 \%$ level. Time dummies, firm size indicators, and individual time average of the time-varying covariates are included in the model specification but not reported for the sake of brevity. The standars errors are robust to within-individual correlation and heteroskedasticity. The standard errors of the predicted probabilities and APEs are obtained by bootstrapping the resuls 399 times (individual-cluster bootstrap with replacement). 
distribution. The state dependence of nonemployment is overestimated: the predicted probability $\widehat{p}_{3}$ and the estimated coefficient of the lagged nonemployment indicator are indeed much larger than those in specification 1. The APE of employment with training instead of employment without training is equal to -0.040 and, therefore, it is slightly overestimated by the failure in capturing cross-equation correlation.

Looking at the impact of exogenous variables on the nonemployment probability, women are less likely to be at work. The profile of the age and nonemployment probability has an inverted U-shape while, ceteris paribus, the probability of being out of the workforce increases with potential work experience. Higher educated people and those living in a couple are more likely to be at work. Those with health problems or high household income are less likely to be employed.

With regard to the firm-provided training equation, there is evidence of state dependence: people getting firm-provided training at $t-1$ are more likely to receive firmprovided training at $t$. It is interesting to note that people not employed at $t-1$ are as likely to receive training at $t$ as those who were at work without training at $t-1$. Higher educated worker are less likely to receive training, but the coefficient is barely significant. There is therefore some evidence that education and firm-provided training are not complementary assets, in contrast to the findings in Blundell et al. (1999) for the US and the UK. The training probability is lower for women with young kids and increasing with the household net income, probably due to less attachment to the labour market and/or more family commitment. Part-time workers are less likely to get firm-provided training. High skilled white collar workers are more likely to get training, suggesting that tasks and human capital formation are complementary assets. Finally, firm-provided training is more present in the services sector, among public employees, and among newly hired workers. ${ }^{10}$

\subsection{Retaining Older Workers}

The workforce is ageing in many industrialized countries. The ageing of the workforce might be caused, in addition to demographic trends, also by the fading out of early retirement programs and by changes in the pension system like changes in the earliest possible or mandatory retirement age. In the 1980s and in the first half of the 1990s, the Netherlands had one of the lowest employment rates of elderly among the European countries. For example, in 1992 the Dutch employment rate of persons aged 55 to 64 was $28.7 \%$

\footnotetext{
${ }^{10}$ Firm size indicators are included in the specification of the training equation (and not reported in Tables 6 and 7) but they are not significantly different from zero.
} 
against an European average of 39.1\%. ${ }^{11}$ Given the economic stagnation in that period, the low employment rates of older workers were not seen as a major problem, whereas the high youth unemployment was thought of being problematic. Early retirement programs were promoted with the aim of giving a contribution to the employment of new entrants in the labour market. However, with the ageing of the population and the resulting pressures on the pension system, the Dutch early retirement system was no longer sustainable. A series of policy reforms were introduced with the aim of reducing the generosity of the early retirement schemes and creating incentives for postponing retirement. Hence, the response to population ageing was based on increasing labour supply and delaying retirement. ${ }^{12}$ By 2009, the employment rate of older workers had increased to 52.6\%, larger than the European average but still lower than the OECD average.

Given the ageing of the workforce, the labour market position of older workers is cause for increasing concern. If employed, their position is usually fine as they are not very likely to be dismissed. As a matter of fact, older workers are well-protected by seniority rules and employment protection legislation. Nevertheless, if older workers lose their job, they find it very hard to find a new one. Gielen and van Ours (2006) show that cyclical adjustments of the workforce in the Netherlands occur partly through fluctuations in separations for older workers. These separations are likely to be a one-way street out of the labour force into long-term unemployment. ${ }^{13}$ Employers are indeed reluctant to hire an older worker because of the pay-productivity gap and because of the possible obsolescence of general human capital. As training can refresh general human capital, avoid its obsolescence, and increase workers' productivity, it can be a channel through which retirement can be postponed and employability of the older workers increased.

In this Section, we focus on the effect of firm-provided training on employability by allowing this effect to be heterogeneous across three age categories: 26-35, 36-49, and 50-64. The corresponding indicator variables are interacted with the lags of the nonemployment indicator and of the firm-provided training indicator. The benchmark model is augmented by these interactions and by the age indicators and re-estimated.

Table 8 reports the estimation results of the coefficients and APEs of primary interest. The coefficient of the interactions between the lag training indicator and the age categories are (jointly) not significantly different from zero. This means that firm-provided training

\footnotetext{
${ }^{11}$ These figures are available in the Eurostat webpage http://stats.oecd.org/Index.aspx?DataSetCode=LFS_SEXAGE_I_R.

${ }^{12}$ Empirical studies found that the Dutch reforms had a positive effect on the labour force participation of older workers (Euwals et al., 2010).

${ }^{13}$ Gielen and van Ours (2006) suggest that training of older workers in public training programs would help them to acquire new skills and to adapt to new demands, such that these workers are more likely to retain their jobs.
} 
Table 8: Dynamic Unobserved Effects Probit Model with Age Interactions

\begin{tabular}{|c|c|c|c|c|c|c|}
\hline \multirow[b]{2}{*}{ Variable } & \multicolumn{3}{|c|}{$\begin{array}{c}\text { Nonemployment } \\
\text { equation }\end{array}$} & \multicolumn{3}{|c|}{$\begin{array}{c}\text { Firm-provided } \\
\text { training equation }\end{array}$} \\
\hline & Coeff. & & S.E. & Coeff. & & S.E. \\
\hline \multicolumn{7}{|c|}{ Reference: employed without firm-provided training and age within $[26,35]$} \\
\hline Nonemployment $_{t-1}$ & $1.405^{\circ}$ & $* * *$ & .058 & -.083 & & .143 \\
\hline Firm-provided training $g_{t-1}$ & -.547 & $* * *$ & .168 & .766 & $* * *$ & .078 \\
\hline Nonemployment $_{t-1} *$ Age $[36,49]$ & .346 & $* * *$ & .063 & -.023 & & .187 \\
\hline Nonemployment $_{t-1} *$ Age $[50,64]$ & .691 & $* * *$ & .073 & -.104 & & .350 \\
\hline Firm-provided training ${ }_{t-1} *$ Age $[36,49]$ & -.062 & & .218 & -.008 & & .095 \\
\hline Firm-provided training $t_{t-1} *$ Age $[50,64]$ & -.042 & & .287 & -.372 & $* *$ & .179 \\
\hline Age $[36,49]$ & -.102 & & .067 & -.116 & & .077 \\
\hline Age $[50,64]$ & -.509 & $* * *$ & .105 & -.046 & & .133 \\
\hline \multicolumn{7}{|l|}{ Predictions and APEs if age $[26,35]$} \\
\hline Predicted probability $\widehat{\pi}_{1}$ & .339 & $* * *$ & .018 & - & & - \\
\hline Predicted probability $\widehat{\pi}_{2}$ & .283 & $* * *$ & .027 & - & & - \\
\hline Predicted probability $\widehat{\pi}_{3}$ & .502 & $* * *$ & .011 & - & & - \\
\hline APE: $\widehat{\pi}_{2}-\widehat{\pi}_{1}$ & -.055 & $* * *$ & .017 & - & & - \\
\hline APE: $\widehat{\pi}_{2}-\widehat{\pi}_{3}$ & -.218 & $* * *$ & .028 & - & & - \\
\hline \multicolumn{7}{|l|}{ Predictions and APEs if age $[36,49]$} \\
\hline Predicted probability $\widehat{\pi}_{1}$ & .328 & $* * *$ & .018 & - & & - \\
\hline Predicted probability $\widehat{\pi}_{2}$ & .268 & $* * *$ & .028 & - & & - \\
\hline Predicted probability $\widehat{\pi}_{3}$ & .532 & $* * *$ & .011 & - & & - \\
\hline APE: $\widehat{\pi}_{2}-\widehat{\pi}_{1}$ & -.060 & $* * *$ & .018 & - & & - \\
\hline APE: $\widehat{\pi}_{2}-\widehat{\pi}_{3}$ & -.265 & $* * *$ & .033 & - & & - \\
\hline \multicolumn{7}{|l|}{ Predictions and APEs if age $[50,64]$} \\
\hline Predicted probability $\widehat{\pi}_{1}$ & .288 & $* * *$ & .021 & - & & - \\
\hline Predicted probability $\widehat{\pi}_{2}$ & .228 & $* * *$ & .040 & - & & - \\
\hline Predicted probability $\widehat{\pi}_{3}$ & .525 & $* * *$ & .013 & - & & - \\
\hline APE: $\widehat{\pi}_{2}-\widehat{\pi}_{1}$ & -.060 & $*$ & .032 & - & & - \\
\hline APE: $\widehat{\pi}_{2}-\widehat{\pi}_{3}$ & -.297 & $* * *$ & .044 & - & & - \\
\hline$N T(N)$ & \multicolumn{6}{|c|}{$33,348(7,257)$} \\
\hline Log-likelihood & \multicolumn{6}{|c|}{$-11,760.6$} \\
\hline No. of parameters & \multicolumn{6}{|c|}{115} \\
\hline Pseudo- $R^{2}$ & \multicolumn{6}{|c|}{.544} \\
\hline \multicolumn{7}{|c|}{$\begin{array}{l}\text { Notes: * Significant at } 10 \% \text { level; ** significant at } 5 \% \text { level; *** significant at } 1 \% \text { level. } \\
\text { All the variables included in the benchmark specification are also included here: the cor- } \\
\text { responding estimated coefficients are not reported for the sake of brevity. The standars er- } \\
\text { rors are robust to within-individual correlation and heteroskedasticity. The standard errors } \\
\text { of the predicted probabilities and APEs are obtained by bootstrapping the resuls } 399 \text { times } \\
\text { (individual-cluster bootstrap with replacement). }\end{array}$} \\
\hline
\end{tabular}


is able to reduce the future probability of being out of the workforce for younger workers as well as for older workers. Note also that the interactions between lag non-employment status and age categories are significantly different from zero and point out that older workers not employed at $t-1$ are more like to be not employed at $t$ than prime aged and young workers. This suggests that once older workers lose their jobs, they are less likely to find a new one. The coefficient of the indicator for older workers is instead significantly negative: older individuals are less likely to lose their jobs and therefore to be out of the workforce.

The estimation of the APEs at the sample means of the other variables confirm that firm-provided training reduces the probability of being not employed with the same magnitude over age classes. An employee with a given set of observed and unobserved characteristics and in the age range 50-64 is 6 percentage points less likely to be out of the workforce at $t$ if she had been employed with training at $t-1$ than if she had been employed without training at $t-1$. This figure is equal to that for employees in the age range 36-49 and slightly bigger in size than that of young workers. There is evidence therefore that firm-provided training substantially increases the employability of older workers as well as the employability of young workers. Firm-provided training might be an important tool to lighten the burden of population ageing on the pension system in the Netherlands.

To some extent training is endogenous to retirement institutions. In 2006 in the public sector in the Netherlands pre-pension plans for every worker born after December 31, 1949 were abolished. To receive the same pension benefits the younger cohort has to postpone retirement for about 13 months. Montizaan et al. (2010) show that this change in future pension benefits had an effect on the expected retirement age and, through this, a positive effect on workers' training participation. We show that this is rational to do since training leads to retaining of jobs. To retain employability of older workers agespecific subsidies to stimulate job training might be used or alternatively age-specific layoff taxes may be introduced. ${ }^{14}$ The first type of policy would it make it more attractive for employers to train older workers thus increasing the likelihood that they retain their employment. The second type of policy would make it more expensive for employers to fire older workers thus making it more attractive to train these workers and thereby increasing the likelihood that they retain their employability.

\footnotetext{
${ }^{14}$ Schnalzenberger and Winter-Ebmer (2009) show that an age-specific firing tax affected the labour market position of older workers in Austria. Employers had to pay a tax of up to $170 \%$ of the gross monthly income when they gave notice to a worker age 50 or more. This tax caused a substantial reduction in layoffs for older workers.
} 


\subsection{Further Robustness Checks}

We perform two further sensitivity analyses to assess whether our estimates are robust to misspecification: i) due to omitting information about individuals who might have attended vocational training courses not provided by the firm; ii) of the dynamics.

With regard to the former, the problem might arise as an omitted time-varying variable indicating whether the employee has undertaken training courses not provided by the firm is very likely to be correlated to the participation to a firm-provided training and, at the same time, to the future employment status. To asses whether this might be a problem, we build an indicator variable $q_{i t}$ equal to 1 if employee $i$ attended vocational education courses which were not paid or organized by the firm since the beginning of the previous year and 0 otherwise. ${ }^{15}$ The incidence of training not provided by the firm is equal to $3.5 \%$ among the employees of our sample. Firstly, we include the variable $q_{i t}$ in the model specification as an exogenous variable and then as a predetermined variable (weak exogenous). In both cases, we find estimation results of the quantities of interest that are very much in line with those of the benchmark model. Secondly, we jointly model the process determining training not provided by the firm and the other two equations of the benchmark model, yielding the following simultanous three-equation model

$$
\begin{aligned}
y_{i t} & =1\left[y_{i t-1} \delta_{1}+w_{i t-1} \gamma_{1}+q_{i t-1} \lambda_{1}+\mathbf{x}_{i t}^{\prime} \beta_{1}+\overline{\mathbf{x}}_{i}^{\prime} \alpha_{1}+y_{i 0} \theta_{1}+w_{i 0} \psi_{1}+q_{i 0} \varphi_{1}+v_{1 i}+u_{1 i t}>0\right] \\
w_{i t} & =1\left[y_{i t-1} \delta_{2}+w_{i t-1} \gamma_{2}+q_{i t-1} \lambda_{2}+\mathbf{z}_{i t}^{\prime} \beta_{2}+\overline{\mathbf{z}}_{i}^{\prime} \alpha_{2}+y_{i 0} \theta_{2}+w_{i 0} \psi_{2}+q_{i 0} \varphi_{2}+v_{2 i}+u_{2 i t}>0\right] \text { if } y_{i t}=0 \\
q_{i t} & =1\left[y_{i t-1} \delta_{3}+w_{i t-1} \gamma_{3}+q_{i t-1} \lambda_{3}+\mathbf{z}_{i t}^{\prime} \beta_{3}+\overline{\mathbf{z}}_{i}^{\prime} \alpha_{3}+y_{i 0} \theta_{3}+w_{i 0} \psi_{3}+q_{i 0} \varphi_{3}+\kappa v_{2 i}+u_{3 i t}>0\right] \text { if } y_{i t}=0,
\end{aligned}
$$

where $\kappa$ is the loading factor determining, together with $v_{2 i}$, the points of support of the equation of training not provided by firms. The loading factor is used to simplify the specification of the unobserved heterogeneity distribution and reduce the computational difficulty in estimating the model. The likelihood function of the benchmark model can be trivially extended to the three-equation case.

Table 9 reports the estimation results of the three-equation model. All the estimates of the nonemployment equation and of the firm-provided equation are in line with those of the benchmark model reported in Table 6. Looking at the equation for training not provided by the firm, it is noted that the past employment status and the past training matter: people who were nonemployed in the past are more likely to train in the future than those who were employed without any form of training. This type of "catch-up" response is in line with the empirical evidence in Mroz and Savage (2006), who found that recent unem-

\footnotetext{
${ }^{15}$ The indicator for vocational training not provided by the firm is built on the basis of variables PT001, PT008, and PT017 of the ECHP data.
} 
Table 9: Dynamic Unobserved Effects Probit Model with 3 Simultaneous Equations

\begin{tabular}{|c|c|c|c|c|c|c|c|c|c|}
\hline \multirow[b]{2}{*}{ Variable } & \multicolumn{3}{|c|}{$\begin{array}{c}\text { Nonemployment } \\
\text { equation }\end{array}$} & \multicolumn{3}{|c|}{$\begin{array}{l}\text { Firm-provided } \\
\text { training equation }\end{array}$} & \multicolumn{3}{|c|}{$\begin{array}{l}\text { Other vocational } \\
\text { training equation }\end{array}$} \\
\hline & Coeff. & & S.E. & Coeff. & & S.E. & Coeff. & & S.E. \\
\hline Nonemployment $_{t-1}$ & 1.725 & $* * *$ & .034 & -.065 & & .102 & .196 & $* *$ & .095 \\
\hline Firm-provided training $g_{t-1}$ & -.479 & $* * *$ & .116 & .779 & $* * *$ & .060 & .201 & $* * *$ & .076 \\
\hline Other vocational training $t_{t-1}$ & .244 & $* * *$ & .093 & .096 & & .089 & 1.386 & $* * *$ & .061 \\
\hline Female & .208 & $* * *$ & .044 & -.009 & & .050 & .044 & & .056 \\
\hline \multicolumn{10}{|c|}{ Education - Reference: Education ISCED 0-2 } \\
\hline Education ISCED 5-7 & -.269 & $* * *$ & .046 & -.102 & $*$ & .058 & -.027 & & .062 \\
\hline Education ISCD 3 & -.206 & $* * *$ & .035 & .008 & & .045 & -.023 & & .049 \\
\hline Age/10 & -1.748 & $* * *$ & .155 & .395 & & .252 & -.271 & & .187 \\
\hline Age squared/1000 & 2.431 & $* * *$ & .179 & -.697 & $* *$ & .326 & .194 & & .247 \\
\hline Work experience/10 & 1.290 & $* * *$ & .186 & -.350 & & .343 & .156 & & .400 \\
\hline Work exper. squared/1000 & .073 & $*$ & .038 & -.003 & & .061 & -.006 & & .075 \\
\hline Bad health & .218 & $* * *$ & .042 & .060 & & .062 & -.130 & & .080 \\
\hline No. household members & .072 & $*$ & .040 & .003 & & .052 & -.106 & & .067 \\
\hline Kids $<12$ years & .229 & $*$ & .128 & .012 & & .110 & .160 & & .170 \\
\hline Kids $<12$ years $*$ Female & .165 & & .147 & -.315 & $* *$ & .156 & -.126 & & .223 \\
\hline Living in a couple & -.490 & $* * *$ & .138 & .055 & & .140 & .051 & & .146 \\
\hline $\ln$ (household net income) & .071 & $* * *$ & .015 & -.039 & $* *$ & .020 & -.001 & & .023 \\
\hline Permanent contract & - & & - & .083 & & .062 & -.103 & & .079 \\
\hline Part-time job & - & & - & -.298 & $* * *$ & .083 & .245 & $* * *$ & .085 \\
\hline Public employment & - & & - & .116 & & .072 & -.148 & & .092 \\
\hline \multicolumn{10}{|c|}{ Occupation indicators - Reference: High-skilled white collar worker } \\
\hline Blue collar & - & & - & -.205 & $* *$ & .086 & -.253 & $* *$ & .106 \\
\hline Low-skilled white collar & - & & - & -.193 & $* * *$ & .064 & .040 & & .076 \\
\hline \multicolumn{10}{|c|}{ Sectoral indicators - Reference: Services } \\
\hline Agriculture & - & & - & .050 & & .381 & .609 & $* *$ & .305 \\
\hline Industry & - & & - & -.218 & $* *$ & .086 & -.030 & & .117 \\
\hline Unknown sector & - & & - & -.321 & $* * *$ & .082 & -.152 & & .105 \\
\hline \multicolumn{10}{|c|}{ Job tenure indicators - Reference: $0-4$ years } \\
\hline Unknown & - & & - & -.289 & $* *$ & .144 & -.009 & & .147 \\
\hline $5-9$ years & - & & - & -.259 & $* * *$ & .066 & .077 & & .086 \\
\hline $10-14$ years & - & & - & -.213 & $* *$ & .092 & .182 & & .144 \\
\hline 15 years or more & - & & - & -.245 & $* *$ & .122 & .230 & & .195 \\
\hline \multicolumn{10}{|c|}{ Initial conditions and unobserved heterogeneity support points } \\
\hline Nonemployment $_{0}$ & 1.389 & $* * *$ & .077 & .417 & $* * *$ & .111 & .119 & & .086 \\
\hline Firm-provided training 0 & -.083 & & .107 & .348 & $* * *$ & .067 & .138 & $*$ & .083 \\
\hline Other vocational training 0 & .004 & $* *$ & .104 & .166 & $* *$ & .081 & .363 & $* * *$ & .069 \\
\hline$\widehat{v}_{j}^{1}$ & 2.005 & $* * *$ & .307 & -2.552 & $* * *$ & .475 & - & & - \\
\hline$\widehat{v}_{j}^{2}$ & .540 & $*$ & .300 & -1.803 & $* * *$ & .509 & - & & - \\
\hline$\widehat{\rho}_{v}$ & -.528 & $*$ & .293 & & & & & & \\
\hline$\widehat{\kappa}$ & & & & & & & .314 & $* *$ & .130 \\
\hline Predicted probability $\widehat{\pi}_{1}$ & .324 & $* * *$ & .015 & - & & - & - & & - \\
\hline Predicted probability $\widehat{\pi}_{2}$ & .279 & $* * *$ & .022 & - & & - & - & & - \\
\hline Predicted probability $\widehat{\pi}_{3}$ & .520 & $* * *$ & .009 & - & & - & - & & - \\
\hline APE: $\widehat{\pi}_{2}-\widehat{\pi}_{1}$ & -.045 & $* * *$ & .015 & - & & - & - & & - \\
\hline APE: $\widehat{\pi}_{2}-\widehat{\pi}_{3}$ & -.241 & $* * *$ & .025 & - & & - & - & & - \\
\hline$N T(N)$ & \multicolumn{9}{|c|}{$33,348(7,275)$} \\
\hline Log-likelihood & \multicolumn{9}{|c|}{$-14,535.4$} \\
\hline No. of parameters & \multicolumn{9}{|c|}{176} \\
\hline Pseudo- $R^{2}$ & \multicolumn{9}{|c|}{.501} \\
\hline Test of independent eq. & \multicolumn{9}{|c|}{$\chi_{1}^{2}=224.98 p$-value $=.000$} \\
\hline
\end{tabular}

Notes: * Significant at $10 \%$ level; ** significant at $5 \%$ level; *** significant at $1 \%$ level. Time dummies, firm size indicators, and individual time average of the time-varying covariates are included in the model specification but not reported for the sake of brevity. The standars errors are robust to within-individual correlation and heteroskedasticity. The standard errors of the predicted probabilities and APEs are obtained by bootstrapping the resuls 239 times (individual-cluster bootstrap with replacement). 
ployment spells has a significant positive effect on whether a young man trains today in the US. As pointed out by Mroz and Savage (2006), the "catch-up" response is predicted by the economic theory: people with a recent nonemployment spell enter the current period with a lower stock of human capital than otherwise identical individuals. When they re-enter the workforce, they dynamically re-optimize their investments in human capital and their new optimal time-path of human capital investments might lie above the one of otherwise identical individuals who did not suffer the employment shock and the loss of human capital.

Table 10: Dynamic Unobserved Effects Probit Model with Lag of Order Two

\begin{tabular}{|c|c|c|c|c|c|c|}
\hline \multirow[b]{2}{*}{ Variable } & \multicolumn{3}{|c|}{$\begin{array}{c}\text { Nonemployment } \\
\text { equation }\end{array}$} & \multicolumn{3}{|c|}{$\begin{array}{l}\text { Firm-provided } \\
\text { training equation }\end{array}$} \\
\hline & Coeff. & & S.E. & Coeff. & & S.E. \\
\hline Nonemployment $_{t-1}$ & 1.884 & $* * *$ & .036 & -.114 & & .126 \\
\hline Nonemployment $_{t-2}$ & .769 & $* * *$ & .042 & .154 & & .108 \\
\hline Firm-provided training $g_{t-1}$ & -.466 & $* * *$ & .115 & .760 & $* * *$ & .060 \\
\hline \multicolumn{7}{|c|}{ Predictions and APEs if the individual was employed at $t-2$} \\
\hline Predicted probability $\widehat{\pi}_{1}$ & .232 & $* * *$ & .030 & - & & - \\
\hline Predicted probability $\widehat{\pi}_{2}$ & .172 & $* * *$ & .035 & - & & - \\
\hline Predicted probability $\widehat{\pi}_{3}$ & .533 & $* * *$ & .015 & - & & - \\
\hline APE: $\widehat{\pi}_{2}-\widehat{\pi}_{1}$ & -.060 & $* * *$ & .016 & - & & - \\
\hline APE: $\widehat{\pi}_{2}-\widehat{\pi}_{3}$ & -.361 & $* * *$ & .046 & - & & - \\
\hline \multicolumn{7}{|c|}{ Predictions and APEs if the individual was not employed at $t-2$} \\
\hline Predicted probability $\widehat{\pi}_{1}$ & .343 & $* * *$ & .019 & - & & - \\
\hline Predicted probability $\widehat{\pi}_{2}$ & .274 & $* * *$ & .031 & - & & - \\
\hline Predicted probability $\widehat{\pi}_{3}$ & .688 & $* * *$ & .029 & - & & - \\
\hline APE: $\widehat{\pi}_{2}-\widehat{\pi}_{1}$ & -.068 & $* * *$ & .019 & - & & - \\
\hline APE: $\widehat{\pi}_{2}-\widehat{\pi}_{3}$ & -.414 & $* * *$ & .056 & - & & - \\
\hline$N T(N)$ & \multicolumn{6}{|c|}{$33,348(7,275)$} \\
\hline Log-likelihood & \multicolumn{6}{|c|}{$-8,999.0$} \\
\hline No. of parameters & \multicolumn{6}{|c|}{103} \\
\hline Pseudo- $R^{2}$ & \multicolumn{6}{|c|}{.550} \\
\hline \multicolumn{7}{|c|}{$\begin{array}{l}\text { Notes: * Significant at } 10 \% \text { level; } * * \text { significant at } 5 \% \text { level; } * * * \text { significant } \\
\text { at } 1 \% \text { level. All the variables included in the benchmark specification are also } \\
\text { included here: the corresponding estimated coefficients are not reported for the } \\
\text { sake of brevity. The standars errors are robust to within-individual correlation } \\
\text { and heteroskedasticity. The standard errors of the predicted probabilities and } \\
\text { APEs are obtained by bootstrapping the resuls } 399 \text { times (individual-cluster } \\
\text { bootstrap with replacement). }\end{array}$} \\
\hline
\end{tabular}

In a second sensitivity analysis, we check whether our findings are robust to the misspecification of the dynamics. We set up a dynamic model where employment status and firm-provided training enter up to the lag of order two. We find that the lag of order two of the firm-provided training indicator does not significantly affect the nonemployment probability ( $p$-value equal to 0.134 ) and thereby removed from the model specification. Table 10 reports the estimation results of the lagged variables. The sample size is now smaller: one more time period is lost as a consequence of the dynamic of higher order. A 
nonemployment event at $t-2$ reinforces the positive effect of a nonemployment event at $t-1$ on the probability of being out of the workforce at $t$. The estimated coefficient of lagged training is qualitatively in line with the one of the benchmark model. We estimated the APEs by conditioning on the nonemployment status at $t-2$. In case of employment at $t-2$, the APE of working with training at $t-1$ rather than working without training at $t-1$ is of -6 percentage points in the probability of being nonemployed (-26\%). If not at work at $t-2$, the APE is equal to -6.8 percentage points $(-20 \%)$. This suggests that the estimated APE $\widehat{\pi}_{2}-\widehat{\pi}_{1}$ of our benchmark model is not sensitive to the dynamic specification and, if any, it suffers from an upward bias. Note however that when we take the model with a dynamic of higher order, we lose observations and we restrict the analysis to individuals that are in the panel for at least four consecutive waves. This makes the assumption of no attrition less likely to hold. We therefore prefer to stick to the specification with a dynamic of order one.

\section{Conclusions}

This paper studies the relationship between on-the-job training and employability in the Netherlands. In our analysis we disentangle the true effect of training from the spurious effect that might be induced by self-selection of non-random individuals into training participation. We find that firm-provided training significantly improves employment prospects. For prime age workers who generally have a strong labour market position, in the sense that after job loss they find a new job quite easily, this relationship may be of limited interest. However, we also investigate whether for older workers training leads to higher employability. We find that older workers who receive on-the-job training are more likely to keep employment.

In many countries the labour market position of older workers is cause for concern. Older workers' job separations are often a one-way street out of the labour force and into long-term unemployment. This is a reason for concern since demographic trends are causing an ageing of the workforce. Therefore, improving the employment position of older workers is very important from a policy point of view. Our research findings suggest that on-the-job training may be an important instrument to achieve this goal. Our research does not provide direct evidence on how to stimulate on-the-job training. Nevertheless we suggest that, in order to retain employability of older workers, age-specific subsidies to stimulate job training might be used or, alternatively, age-specific layoff taxes may be introduced. The first type of policy would make it more attractive for employers to train older workers, thus increasing the likelihood that they retain their employability. The 
second type of policy would make it more expensive for employers to fire older workers, thus making it more attractive to train these workers and thereby increasing the likelihood that their employment prospects improve.

\section{References}

Alessie R, Hochguertel S, van Soest A. 2004. Ownership of stocks and mutual funds: A panel data analysis. Review of Economics and Statistics 86: 783-796.

Andrén T, Andrén D. 2006. Assessing the employment effects of vocational training using a one-factor model. Applied Economics 38: 2469-2486.

Barrett A, O'Connell P. 2001. Does training generally work? The returns to in-company training. Industrial and Labor Relations Review 54: 647-662.

Bartel A. 1994. Productivity gains from the implementation of employee training programs. Industrial Relations 33: 411-425.

Bartel A. 1995. Training, wage growth, and job performance: Evidence from a company database. Journal of Labor Economics 13: 401-425.

Bassi L. 1984. Estimating the effect of training programs with non-random selection. Review of Economics and Statistics 66: 36-43.

Blundell R, Dearden L, Meghir C, Sianesi B. 1999. Human capital investments: The returns from education and training to the individual, the firm, and the economy. Fiscal Studies 20: 1-23.

Bonnal L, Fougère D, Sérandon A. 1997. Evaluating the impact of French employment policies on individual labour market histories. Review of Economic Studies 64: 683-713.

Boone J, van Ours J. 2009. Bringing unemployed back to work: Effective active labor market policies. De Economist 157: 293-313.

Chamberlain G. 1984. Panel data. In Grichiles Z, Intriligator M (eds.) Handbook of Econometrics, chapter 22. Amsterdam: North Holland, 1248-1318.

Conti G. 2005. Training, productivity and wages in Italy. Labour Economics 12: 557-576.

Crépon B, Ferracci M, Fougère D. 2007. Training the unemployed in France: How does it affect unemployment duration and recurrence? IZA Discussion Paper No. 3215, Bonn.

Dearden L, Reed H, Van Reenen J. 2006. The impact of training on productivity and wages: Evidence from British panel data. Oxford Bulletin of Economics and Statistics 68: 397-421.

Euwals R, van Vuuren D, Wolthoff R. 2010. Early retirement behaviour in the Netherlands: Evidence from a policy reform. De Economist 158: 209-236.

Gerfin M, Lechner M. 2002. A microeconometric evaluation of the active labour market policy in Switzerland. Economic Jounal 112: 854-893. 
Gielen A, van Ours J. 2006. Age-specific cyclical effects in job reallocation and labor mobility. Labour Economics 13: 493-504.

Gritz R. 1993. The impact of training on the frequency and duration of employment. Journal of Econometrics 57: $21-51$.

Ham J, LaLonde R. 1996. The effect of sample selection and initial conditions in duration models: Evidence from experimental data on training. Econometrica 64: 175-205.

Heckman J. 1981. The incidental parameters problem and the problem of initial conditions in estimating a discrete time-discrete data stochastic process. In Manski C, McFadden D (eds.) Structural Analysis of Discrete Data with Econometric Applications, chapter 4. Cambridge: MIT Press, 179-195.

Heckman J, RJ L, JA S. 1999. The economics and econometrics of active labor market programs. In OC A, D C (eds.) Handbook of Labor Economics, volume 3A, chapter 31. Amsterdam: Elsevier, 1865-2097.

Heckman J, Singer B. 1984. A method for minimizing the impact of distributional assumptions in econometric models for duration data. Econometrica 52: 271-320.

Hyslop D. 1999. State dependence, serial correlation and heterogeneity in intertemporal labor force participation of married women. Econometrica 67: 1255-1294.

Jones M, Jones R, Latreille P, Sloane P. 2009. Training, job satisfaction, and workplace performance in Britain: Evidence from WERS 2004. Labour 23: 139-175.

Kluve J. 2010. The effectiveness of European active labour market programmes. Labour Economics 17: 904-918.

Lalive R, van Ours J, Zweimüller F. 2008. The impact of active labour market programmes on the duration of unemployment in Switzerland. Economic Journal 118: 235-257.

Lechner M, Miquel R, Wunsh C. 2008. The curse and blessing of training the unemployed in a changing economy: The case of East Germany after unification. German Economic Review 8: 468-509.

Montizaan R, Corvers F, Grip AD. 2010. The effects of pension rights and retirement age on training participation: evidence from a natural experiment. Labour Economics 17: 240-247.

Mroz T, Savage T. 2006. The long-term effects of youth unemployment. Journal of Human Resources 41: 259-293.

Mundlak Y. 1978. On the pooling of time series and cross section data. Econometrica 46: 69-85.

OECD. 2010. Employment Outlook. Paris.

Pavlopoulos D, Muffels R, Vermunt J. 2009. Training and low-pay mobility: The case of the UK and the Netherlands. Labour 23: 37-59.

Picchio M. 2008. Temporary contracts and transitions to stable jobs in Italy. Labour 22: 147-174.

Picchio M, van Ours J. 2011. Market imperfections and firm-sponsored training. Labour Economics 18: forthcoming. 
Ridder G. 1986. An event history approach to the evaluation of training, recruitment and employment programmes. Journal of Applied Econometrics 1: 109-126.

Sanders J, de Grip A. 2004. Training, task flexibility and the employability of low-skilled workers. International Journal of Manpower 25: 73-89.

Schnalzenberger M, Winter-Ebmer R. 2009. Layoff tax and employment of the elderly. Labour Economics 16: 618-624.

Sianesi B. 2008. Differential effects of active labour market programs for the unemployed. Labour Economics 15: 370-399.

Stewart M. 2007. The interrelated dynamics of unemployment and low-wage employment. Journal of Applied Econometrics 22: 511-531.

van den Berg G, Lindeboom M. 1998. Attrition in panel survey data and the estimation of multi-state labor market models. Journal of Human Resources 33: 458-478.

van den Berg G, Ridder G. 1994. Attrition in longitudinal panel data and the empirical analysis of dynamic labour market behaviour. Journal of Applied Econometrics 9: 421-435.

Wooldridge J. 2005. Simple solutions to the initial conditions problem in dynamic, nonlinear panel data models with unobserved heterogeneity. Journal of Applied Econometrics 20: 39-54. 